NBER WORKING PAPER SERIES

\title{
PUZZLING TAX STRUCTURES IN DEVELOPING COUNTRIES: A COMPARISON OF TWO \\ ALTERNATIVE EXPLANATIONS
}

\author{
Roger Gordon \\ Wei Li \\ Working Paper 11661 \\ http://www.nber.org/papers/w11661
NATIONAL BUREAU OF ECONOMIC RESEARCH
1050 Massachusetts Avenue
Cambridge, MA 02138
September 2005

We would like to thank participants at EASE-16, and especially Andrew Rose, Francis Liu, and Michael Alba for comments on an earlier draft. We would also like to thank the World Bank for financial support for this project. The views expressed herein are those of the author(s) and do not necessarily reflect the views of the National Bureau of Economic Research.

(C2005 by Roger Gordon and Wei Li. All rights reserved. Short sections of text, not to exceed two paragraphs, may be quoted without explicit permission provided that full credit, including $\odot$ notice, is given to the source. 
Puzzling Tax Structures in Developing Countries: A Comparison of Two Alternative Explanations

Roegr Gordon and Wei Li

NBER Working Paper No. 11661

September 2005

JEL No. H21, O23, O17, F13, F23

\begin{abstract}
Observed economic policies in developing countries differ sharply both from those observed among developed countries and from those forecast by existing models of optimal policies. For example, developing countries rely little on broad-based taxes, and make substantial use of tariffs and seignorage as nontax sources of revenue.

The objective of this paper is to contrast the implications of two models designed to explain such anomalous policies. One approach, by Gordon-Li (2005), focuses on the greater difficulties faced in poor countries in monitoring taxable activity, and explores the best available policies given such difficulties. The other, building on Grossman-Helpman (1994), presumes that political-economy problems in developing countries are worse, leading to worse policy choices. The paper compares the contrasting theoretical implications of the two models with the data, and finds that the politicaleconomy approach does poorly in reconciling many aspects of the data with the theory. In contrast, the forecasts from Gordon-Li model are largely consistent with the data currently available.
\end{abstract}

\author{
Roger H. Gordon \\ Department of Economics 0508 \\ UC, San Diego \\ 9500 Gilman Drive \\ La Jolla, CA 92093 \\ and NBER \\ rogordon@ucsd.edu \\ Wei Li \\ University of Virginia \\ Darden Graduate School of Business \\ Administration \\ Box 6550 \\ Charlottesville, VA 22906-6550 \\ liw@darden.virginia.edu
}




\title{
Puzzling Tax Structures in Developing Countries: A Comparison of Two Alternative Explanations
}

\author{
by \\ Roger Gordon and Wei Li*
}

\begin{abstract}
Observed economic policies in developing countries differ sharply both from those observed among developed countries and from those forecast by existing models of optimal policies. For example, developing countries rely little on broad-based taxes, and make substantial use of tariffs and seignorage as nontax sources of revenue.
\end{abstract}

The objective of this paper is to contrast the implications of two models designed to explain such anomalous policies. One approach, by Gordon-Li (2005), focuses on the greater difficulties faced in poor countries in monitoring taxable activity, and explores the best available policies given such difficulties. The other, building on Grossman-Helpman (1994), presumes that political-economy problems in developing countries are worse, leading to worse policy choices. The paper compares the contrasting theoretical implications of the two models with the data, and finds that the political-economy approach does poorly in reconciling many aspects of the data with the theory. In contrast, the forecasts from Gordon-Li model are largely consistent with the data currently available.

Economic policies in developing countries often differ sharply from those commonly advocated by economists, generating advice to adopt policies more consistent with both the successful practices in richer countries and/or those that appear best based on existing economic theories.

For example, economists advocate a stable currency and low tariff rates. Yet inflation rates in developing countries are often high, as are tariff rates.

\footnotetext{
* We would like to thank participants at EASE-16, and especially Andrew Rose, Francis Liu, and Michael Alba for comments on an earlier draft. We would also like to thank the World Bank for financial support for this project.
} 
Economists advocate setting up procedures to protect property rights, and establishing a rule of law in particular to aid in the legal enforcement of contracts and in dispute resolution. Yet, complaints by firms in developing countries about costly and timeconsuming procedures, under-the-table fees, and arbitrary outcomes are common.

Economists strongly discourage state ownership of firms. ${ }^{1}$ Yet in developing countries state ownership of firms is common. State ownership of banks is even more common.

Taxes certainly require some interference with market transactions, so the advice would be to enact taxes with a broad base and low rates so as to lessen the efficiency costs resulting from the distortions created by the tax structure. Broad-based taxes, such as a value-added tax, certainly do play an important role in poorer as well as richer countries. However, a much larger share of revenue in developing than in developed countries comes from taxes with a narrow base. Even when broad-based taxes are used, the evidence suggests that in practice revenue is collected from only a fraction of the activity that by statute should be covered.

In each case, economists normally advocate a shift towards policies that reduce interference in the functioning of markets.

If existing policies in poorer countries are so costly, though, why are such policies adopted to begin with? The deviation from conventionally recommended policies is systematic among poorer countries, and has existed for many years, making it hard to dismiss this evidence as being a result of some officials misunderstanding the implications of the policies they choose. Why would developing countries choose to impose such costs on themselves?

A common explanation for such seemingly perverse policies in developing economies falls under the general category of "political economy" problems. Here, the presumption

\footnotetext{
${ }^{1}$ Where monopoly power is present, exceptions might be made, though even here government regulatory oversight is typically preferred to government ownership.
} 
is that these policies are designed to benefit select groups within a country who have unusually strong political influence. In particular, a government can favor these groups by designing the tax system to transfer resources to them, and perhaps by interfering with market allocations so as to alter equilibrium market prices in ways that benefit particular favored industries. But these policies may still impose large costs on the rest of the population, justifying altruistic intervention from outside.

Gordon and Li (2005) develop an alternative hypothesis for such policies. Here, the key assumption is that poorer countries face much more severe enforcement problems with their tax system. Enforcement depends heavily on the availability of information from outside a firm about the scale of any firm's economic activities. Such information, largely coming from the firm's recorded transactions through the financial sector, is essential to double-check the information reported by the firm. When firms use the financial sector, they leave a paper trail, facilitating tax enforcement. In contrast, cash transactions are virtually impossible to monitor and tax, to the point that the informal economy and the cash economy are often used as synonyms. When countries have both a financial sector that provides little value-added to firms, and firms that receive very heterogeneous benefits from using the financial sector, then the forecasted outcome is high tax rates in practice paid only by those firms strongly dependent on the financial sector, so a narrow tax base, with other firms avoiding tax through relying entirely on cash transactions. The result can be large intersectoral distortions favoring the informal economy.

Gordon and $\mathrm{Li}$ (2005) then argue that the government can lessen these intersectoral distortions through tariff protection of firms facing high effective tax rates, through inflation as a tax on firms that rely on cash to avoid tax, through controls on lending so as to redirect credit to heavily taxed sectors, and through red tape and fees that impose nontax costs on businesses that in practice pay little or no taxes.

Section 1 provides a derivation of the forecasted tax policy coming from a GrossmanHelpman (1994) style political economy model, and a comparison of these forecasts with 
those derived in Gordon-Li (2005). The forecasts from the two models differ in many respects. The political economy model certainly forecasts favorable tax treatment of sectors that can lobby the government effectively. However, while the model forecasts lower or even negative tax rates on income earned in favored sector, as long as such means are available to aid these industries it does not forecast tariff protection for these sectors, ${ }^{2}$ inflation, or other forms of interference with market transactions. The theory would not forecast an informal (untaxed) sector, at least beyond the sectors that are effective in lobbying the government. Unlike in the Gordon-Li model, tariff protection and subsidized credit should be for sectors that face relatively low tax rates, rather than relatively high tax rates. The two models also have contrasting forecasts for the size of government and the progressivity of the tax structure in poor vs. rich countries.

In section 2, we look at the empirical evidence more closely to compare the evidence with the forecasts from these two models. Some forecasts are shared by the models and some contrast. This evidence is almost entirely consistent with the forecasts from the Gordon-Li model, and almost entirely inconsistent with the forecasts from the politicaleconomy model. Section 3 then contains a brief set of concluding remarks.

\section{Alternative forecasts for economic policies}

\section{Conventional model}

In this section, we develop the implications of a political economy model, and summarize the implications of the Gordon-Li model in a simple setting. To set the context, though, we first develop a model of policy in a more conventional setting.

Assume that the country is small and open, so is a price taker in the international market for the two consumption goods. These international prices are denoted by $p_{1}$ and $p_{2}$.

\footnotetext{
${ }^{2}$ To the extent that tax rates cannot vary by industry to the extent desired, however, then the model does forecast tariff protection and subsidized credit to favored firms.
} 
Both goods are produced in the domestic economy, and the domestic wage rate, $w$, and domestic interest rate, $r$, adjust to clear factor markets. Assume that good 2 is imported and good 1 is exported. ${ }^{3}$

The government is considering the choice of tax rates on the domestic output of the two goods, denoted by $s_{1}$ and $s_{2}$, along with a tariff at rate $\tau_{2}$ on imports of good $2,{ }^{4}$ and a tax at rate $t_{K}$ on domestic capital. Consumer prices are then equal to $p_{i}\left(1+\tau_{i}\right)$. The netof-tax prices domestic firms face for output of the two goods are $p_{i}\left(1+\tau_{i}\right)\left(1-s_{i}\right)$, while the user cost of capital to a firm is $r+t_{K}$.

The indirect utility function for individual $i$ is denoted by $V_{i}\left(p_{1}\left(1+\tau_{1}\right), p_{2}\left(1+\tau_{2}\right), r, w\right)+W_{i}(G)$, where $G$ measures expenditures on public services. A conventional model for optimal tax policy assumes that the government chooses Pareto efficient policies, so maximizes a weighted sum of the welfare of individuals and the utility of government officials, who consume what tax revenue is left net of the cost of public services: ${ }^{5}$

$$
\max _{\tau_{2}, s_{1}, s_{2}, t_{K}, G}\left\{\sum_{i}\left(V_{i}\left(p_{1}\left(1+\tau_{1}\right), p_{2}\left(1+\tau_{2}\right), r, w\right)+W_{i}(G)\right)+U(R-G),\right.
$$

Using the aggregate economy's budget constraint, tax revenue $R$ equals gross domestic output minus domestic consumption, all evaluated at world prices: $R=\sum_{j} p_{j}\left(f_{j}-C_{j}\right)$.

By maximizing over the size of government services, $G$, trading off benefits to residents with foregone consumption of government officials, we can rewrite the government's objective function as:

\footnotetext{
${ }^{3}$ Here, we assume that workers and capital can move without cost between the two domestic industries, so that there is one set of factor prices characterizing the economy as a whole.

${ }^{4} \mathrm{We}$ also include in the notation a placeholder tariff on good 1 , denoted $\tau_{1}$, just to simplify some of the notation, even though we normalize the tariffs by setting $\tau_{1}=0$.

${ }^{5}$ This model simultaneously captures the behavior of both "benevolent" and "malevolent" governments, by allowing officials to extract private benefits from unspent tax revenue, but also having them care about individual utilities.
} 


$$
\max _{\tau_{2}, s_{1}, s_{2}, t_{K}} \sum_{i}\left(V_{i}\left(p_{1}\left(1+\tau_{1}\right), p_{2}\left(1+\tau_{2}\right), r, w\right)\right)+S\left(\sum_{j} p_{j}\left(f_{j}-C_{j}\right)\right)
$$

for some function $S($.) that captures the overall benefits from extra tax revenue.

This model is the basic framework used in deriving optimal tax rates. To replicate a tax rate on labor income, there would need to be a uniform sales tax rate $\left(s_{1}=s_{2}\right)$ along with implicit expensing for capital investments $\left(r t_{K}=-s_{1}\right)$. Taxes on capital income may well arise in such a derivation, and would appear through a tax rate on capital above this figure. Distortions to relative consumer prices could be implemented through a tariff along with an offsetting tax on domestic production of that good, as happens with a VAT. Such distortions could arise, for example, if those with a low marginal utility of income have high relative demand for one of the two goods. To preserve productive efficiency, however, as forecast by Diamond and Mirrlees (1971), the model would require that

$$
\frac{p_{1}\left(1-s_{1}\right)}{p_{2}\left(1+\tau_{2}\right)\left(1-s_{2}\right)}=\frac{p_{1}}{p_{2}}
$$

so that sales tax rates adjust to compensate for any tariffs, so as to leave the net-of-tax price faced by producers unchanged by the introduction of the tariff.

In such a setting, there are no grounds for interfering further with market allocations: as forecast by Diamond-Mirrlees, production should remain efficient. As a result, the model cannot help explain state ownership of firms or banks, or any government regulations interfering with market allocations. As set up here, the model does not include a role for "money," so does not allow an analysis of the optimal inflation rate. One simplified way to introduce money into the model is by including real cash balances as a third consumer good. To replicate a proportional tax on labor income, the sales tax rates should again by equal across goods, implying an equal proportional mark-up over the real costs of each good. The real cost of money, as noted by Friedman (1956) is virtually zero, implying a price of money so a nominal interest rate of virtually zero. 


\section{Gordon-Li model}

Gordon and $\mathrm{Li}$ (2005) add one new issue into the above model: tax enforcement. They assume that firms can be monitored and taxed only if they make use of the financial sector, thereby leaving a paper trail. The real benefits of using the financial sector, per se, for a firm in industry $j$ is assumed to equal $a_{j} p_{j}\left(1+\tau_{j}\right) f_{j}$, so is proportional to the value of the firm's output. The cost of using the financial sector is that the firm becomes subject to tax. ${ }^{6}$ Since pretax output from a firm using the financial sector is $\left(1+a_{j}\right)\left(1+\tau_{j}\right) p_{j} f_{j}$, sales tax and capital tax payments would together equal $s_{j} p_{j}\left(1+\tau_{j}\right)\left(1+a_{j}\right) f_{j}+t_{K} K_{j}$. Firms then make use of the financial sector only if benefits exceed costs, or if

$$
a_{j}\left(1+\tau_{j}\right) p_{j} f_{j}>s_{j}\left(1+\tau_{j}\right) p_{j}\left(1+a_{j}\right)+t_{K} K_{j}
$$

This adds to the conventional analysis a set of constraints on the feasible tax rates imposed on each industry. Any tax rates violating equation (2) will induce disintermediation and collect no revenue from that industry.

In richer countries, use of the financial sector may be valuable enough that none of these constraints are binding. In poorer countries, though, the financial sector may operate much less well (the $a_{j}$ are smaller), so that these constraints become an important consideration in any discussion of tax policy. The lower are the $a_{j}$ within a country, the lower are feasible tax rates and as a result the lower would be government revenue. As seen below, government revenue as a fraction of GDP is in fact much lower in poorer than in richer countries. The conventional model, in contrast, does not help explain this unless government revenue is less valued in poorer countries.

\footnotetext{
${ }^{6}$ Tariffs are collected regardless.
} 
The presumption in Gordon and $\mathrm{Li}$ is that capital-intensive industries will value much more the use of the financial sector, so have a higher $a_{j}{ }^{7}$ To begin with, this will imply a higher $s_{j}$ in capital-intensive industries when some of the constraints in equation (2) become binding.

When firms within each industry are homogeneous and the government can set a separate sales tax rate for each industry, then tax rates would be set so that all firms satisfy the constraints in equation (2). Any sales tax rate in an industry high enough to violate equation (2) would create a Pareto loss, since the government would lose its tax base in that industry while firms are left indifferent, relative to a rate that just satisfies equation (2).

When firms within an industry are heterogeneous, though, then a higher $s_{j}$ will collect more revenue from some firms while inducing others to shift into the cash economy. Depending on the distribution of the $a_{j}$ within an industry, tax rates can potentially be quite high, with some firms paying this high tax rate and others avoiding it through disintermediation. The conventional model does not include any structure sufficient to explain the presence of an informal economy.

Given differences in the optimal $s_{j}$ across industries, Gordon and Li then explore the role of various other policies to lessen the misallocations resulting from differences in the optimal $s_{j}$ across industries in response to the constraints in equation (2). Tariffs may now be used even if they would not be used otherwise. Not only can tariffs help collect additional revenue, but they can also lessen the distortions created by the differential sales tax rates by industry by shifting domestic production into the heavily taxed

\footnotetext{
${ }^{7}$ This could occur because capital-intensive firms are larger so have more customers who are physically distant, making use of financial intermediaries to handle payments of more value. Capital-intensive firms will also face lumpy expenditures to purchase capital, making bank loans of more value. To convince banks of their credit worthiness, maintaining an active account with the bank may be essential. Larger firms may also not be able to effectively monitor all of the employees who handle cash, and prefer instead to shift to noncash payments through use of the banking sector.
} 
industries. If the heavily taxed good is imported, then these two potential benefits reinforce and trade will be discouraged. In contrast, if the heavily taxed good is exported then these two potential benefits conflict and trade may even be encouraged.

Money is now demanded in particular by firms that avoid taxes by joining the cash economy, so that inflation becomes a targeted tax on firms otherwise avoiding tax. ${ }^{8}$ The larger the informal sector the higher the benefits relative to the costs of inflation.

Capital taxes can help focus tax liabilities on capital-intensive firms, who are the most tied to using the financial sector so the least likely to shift into the informal sector in response.

Given the efficiency costs arising from a shift of activity out of the most highly taxed (capital-intensive) sectors, one mechanism to reduce this shift is state ownership of the most capital-intensive firms. Through state-ownership, the government can in principle ensure that the sector has the efficient scale and capital intensity. This potential efficiency gain can quickly become large as tax rates increase, and with high enough tax rates can dominate the efficiency loss that occurs due to state ownership per se.

An alternative mechanism to increase the scale of activity in the heavily taxed sectors is to provide them cheap credit. This can be done through state-ownership of the banking sector. While providing cheap credit to heavily taxed firms results in losses for the stateowned banks, the government can in principle cover these losses through the resulting tax revenue collected from the extra capital invested in these heavily taxed sectors.

Government red tape and regulatory controls on firm entry can be another mechanism to hinder activity in lightly taxed if not entirely untaxed sectors. Even if no revenue is collected directly through such intervention, to the extent domestic production shifts as a

\footnotetext{
${ }^{8}$ The feasible "inflation" tax would itself be constrained, though, by the option firms have to use a foreign rather than a domestic currency for transactions.
} 
result into more heavily taxed sectors there can still be a net efficiency benefit from such policies.

To see this more formally, consider an individual's choice between being an employee in the formal sector vs. working in the informal sector. We assume that the individual makes this choice to maximize indirect utility of $V(w) .{ }^{9}$ Within the formal sector, the effective wage rate for individual $j$ is $w_{j}=\left(1-s_{j}\right) p_{j} f_{L j}$, where $f_{L j}$ measures the marginal product of labor in the industry. Let the effective wage rate in the informal sector be $\left(1+n_{j}\right) p_{j} f_{L j}$. Here, $n_{j}$ is a parameter that varies by individual, reflecting that individual's best available informal jobs and the value of $a_{j}$ (positive or negative) in that sector, so can be either positive or negative. There is some joint density function $g\left(w_{j}, n_{j}\right)$ for $w_{j}$ and $n_{j}$. Without government intervention, the individual shifts to the informal sector whenever $n_{j}>-s_{j}$.

The government is affected by this choice, though, given that output in the formal sector is taxable whereas output in the informal sector is not. If output in the formal sector is subject to a sales tax at rate $s$, then tax revenue drops by $s w_{j} L_{j} /(1-s)$ if the individual leaves the formal sector. Individual choices are then inefficient, since they ignore this fiscal externality.

What if at some cost, $F$, the government can hire tax inspectors to locate and identify businesses operating in the informal sector? We assume that these inspectors cannot observe $\left(1+n_{j}\right) p_{j} f_{L j}$, nor hours of work, but only the fact that the individual is working in the informal sector. Many of the people working in the informal sector presumably are extremely poor, ${ }^{10}$ making it unattractive on distributional grounds to impose a fixed monetary fee for working in the informal sector. Instead, consider the imposition of nontax (time) costs on firms in the informal sector, generated through red

\footnotetext{
${ }^{9}$ The other arguments of $V$ are surpressed, to economize on notation.

${ }^{10}$ One possible explanation for this is that capital and skilled labor are complementary in production, so that the capital-intensive firms in the formal sector employ very few unskilled workers.
} 
tape. Assume in particular that the government can impose a time cost of $H$ on each individual in the informal sector. ${ }^{11}$ Then the individual shifts into the informal sector if and only if $\left(1+n_{j}\right) p_{j} f_{L j}(L-H)>\left(1-s_{j}\right) p_{j} f_{L j} L$ or equivalently if $n_{j}>\left(H-s_{j} L\right) /(L-H)$.

Even though red tape imposes costs on those in the informal sector while collecting no revenue directly, still the government may well choose to create red tape. The key gain is the resulting shift of higher skilled individuals into the formal sector, with the resulting increase in tax revenue.

Stated formally, start from $H=0$ and consider the change in the government's objective function from a marginal increase in $H$ :

$$
-\int_{0}^{\infty} \int_{-s}^{\infty} V_{I}(1+n) w g(w, n) d n d w+S^{\prime} \int_{0}^{\infty}\left(\frac{s}{1-s}\right) w L \frac{\partial n^{*}}{\partial H} g(w,-s) d w,
$$

where $n^{*}=(H-s L) /(L-H)$ represents the skill level just indifferent between being in the formal or the informal sectors, so that $\partial n^{*} / \partial H=(1-s) / L$ evaluated at $H=0$. Expression (3) can easily be positive, in which case red tape is a useful means of expanding the formal sector. This is more likely to occur to the extent that $S^{\prime}>>V_{I}$ and $s \gg 0$, implying in addition that the average value of $n$ among those in the informal sector will be small or negative.

The Gordon-Li model took the range of values of the $a_{j}$, measuring the value to each firm $j$ of making use of the financial sector, as exogenous. While the state of skills and technology within the financial sector are largely outside of the direct control of the

\footnotetext{
${ }^{11}$ What if tax inspectors can learn each individual's productivity? They would then have an incentive to charge a firm an amount just sufficient to leave them indifferent to remaining in the informal sector, given $H$, enforced by the threat of revealing their income to the tax authorities. The only substantive change is a redistribution from informal firms to tax inspectors, leading in equilibrium to a fall in the amount $F$ they require in wages from the government. Given such a fall in the expense of imposing the costs $H$ on informal firms, the government may encourage such corruption.
} 
government, the government does control the regulatory environment under which the financial sector operates. Changes such as providing deposit insurance, or speeding the clearing of interbank payments, presumably will shift up the distribution of the $a_{j}$. Surprisingly, the government does not necessarily have an incentive to adopt such policies, even given the objective function we have assumed. Consider the welfare effects of an increase in the values of $a_{j}$ in industries at the bottom end of the distribution, sufficient to pull firms in these industries into the formal sector. They now pay at least some taxes, in itself a welfare gain. ${ }^{12}$ By documenting their activity with a bank, firms entering the formal sector should also now qualify for bank credit that they would not previously have had access to. This credit comes at the expense of loans to firms in industries already in the formal sector, who in this example face higher tax rates. On net, tax revenue could well fall, with the drop in payments from high-taxed sectors perhaps more than offsetting the taxes paid by firms newly entering the formal sector. When the behavioral responses lead to a fall in tax revenue, efficiency falls as well, so that such an improvement in the performance of the financial sector may not be an attractive option to the government.

Of course, large enough improvements in the $a_{i}$ will necessarily be a welfare gain, since the constraints in equation (2) all become less binding and eventually nonbinding. Policy will change continuously with the relaxation of these constraints. In particular, as the financial sector improves, to begin with we expect to see a drop in the size of the informal sector, and with the broader tax base less extreme tax rates on the most capitalintensive firms. With smaller intersectoral distortions, the need for distorting tariffs, inflation, state ownership of firms or banks, and use of capital taxes, all drop.

One example of such a transition in policy, an example that led us to develop this model, is the case of China during the 1990's, as described in Gordon and Li (2005a). At the beginning of this decade, the national government was unable to collect much of any

\footnotetext{
${ }^{12}$ When firms just become willing to shift into the formal sector, by construction they are just indifferent. But the government receives extra revenue, so that there is a gain in overall welfare, and in efficiency.
} 
revenue from small and medium sized firms, so that its tax revenue came almost entirely from taxes on larger state-owned firms. ${ }^{13}$ It's observed policies were very much consistent with those forecast above, with tax rates that varied strongly by sector, controls over the allocation of credit, and high tariff rates. ${ }^{14}$ In 1994, there were a series of reforms that led to a sharp increase in the national government's ability to collect taxes from small and medium-sized firms. ${ }^{15}$ With this successful attempt to broaden its tax base, the national government shifted policy generally away from the policies forecast above towards a set of more conventional policies, agreeing to cut tariffs through joining the WTO, eliminating government control over lending practices at the banks, shifting heavily away from reliance on sector-specific excise taxes and taxes on capital (corporate income taxes) towards a broad-based VAT, and beginning the process of downsizing the size of the SOE sector, and the role of the government in this sector.

Even when increasing the value provided by the financial sector does raise welfare, however, it does not follow that subsidies to the financial sector, artificially raising the values of the $a_{i}$, raise welfare. Intuitively, a competitive banking sector will in equilibrium pass along the value of any subsidies to its customers, so that the maximum tax these customers will be willing to pay to make use of the banking sector goes up by just the size of the subsidy. The extra tax payments are then just sufficient to cover the cost of the subsidy.

More formally, assume that the costs to the bank of supplying services to firms in industry $j$, per dollar of sales that must be intermediated, is $x_{j}$, implying total costs of $x_{j} p_{j}\left(1+\tau_{j}\right) f_{j}$. Similarly, assume the gross benefits to firms in industry $j$ from using the banks are $b_{j} p_{j}\left(1+\tau_{j}\right) f_{j}$. With a competitive banking sector, the price firms pay for

\footnotetext{
${ }^{13}$ In particular, local governments were responsible for monitoring and assessing taxes on small and medium-sized firms, and were effective in hiding taxable activity from the national government.

${ }^{14}$ There was little use of inflation, however.

${ }^{15}$ An important part of this tax reform had the national government take over responsibility from local governments for monitoring and assessing taxes on smaller firms. In China, the role of the financial sector in tax enforcement was much more limited than in other developing countries, since each firm had a party representative whose job in part was to monitor the taxable activity of the firm. The level of government to which this party representative was responsible changed as of 1994.
} 
banking services equals the cost of provision of these services, so that the net benefits to firms equal $\left(b_{j}-x_{j}\right) p_{j}\left(1+\tau_{j}\right) f_{j} \equiv a_{j} p_{j}\left(1+\tau_{j}\right) f_{j}$. What if the government now provides a subsidy to the provision of financial services to this industry, paying some amount $\sigma_{j} p_{j}\left(1+\tau_{j}\right) f_{j}$ to the banks? With a competitive banking sector, this subsidy will be passed along to the customers in the form of a lower price, so that the net benefits to a firm from using the financial sector rise to $\left(a_{j}+\sigma_{j}\right) p_{j}\left(1+\tau_{j}\right) f_{j}$. Following the logic of equation (2), this figure now equals the maximum taxes that can be collected from this industry. Subtracting off the costs of the subsidy, however, the maximum net revenue from this industry remains equal to $a_{j} p_{j}\left(1+\tau_{j}\right) f_{j}$. As long as all tax rates can adjust, the same revenue on net is collected with the subsidy as without.

The same argument also implies that taxes on the financial sector crowd out other sources of revenue one for one. Since it would be very difficult to design the tax structure on the financial sector to replicate the flexibility the government has in choosing each of the sales tax rates and the capital-income tax rate, taxes on the financial sector will normally end up being less effective than taxes on each of the industries making use of the financial sector.

\section{Political Economy model}

There are a variety of modeling approaches taken within the political economy literature to characterize the nature of the implicit objectives faced by the government when choosing policies. The approach we take is inspired by the work of Grossman and Helpman (1994), who assume that special interests that have solved their internal freerider problem can provide "contributions" to a party in power linked at the margin to the degree to which the party aids that interest group. The result is that the government puts more weight on the utility of that interest group than it otherwise would.

To explain more perverse policies in developing countries, the presumption is then that these contributions distort policy more severely in developing than in developed 
countries. Distortions are least costly in the Grossman-Helpman framework when either no industries or all industries contribute, since in either case the weights remain undistorted across industries. If we assume that most all industries in developed countries actively lobby the government, then developing countries end up with worse policies if a smaller fraction of industries are able to lobby effectively.

Solving the free-rider problem within an industry is easier when there are fewer firms in the industry. We presume that capital-intensive industries have larger individual firms and fewer firms in the industry as a whole, so that the subset of industries able to lobby the government will largely represent the most capital-intensive sectors.

One issue, though, is how to capture the benefits going to an industry from any given government policies, since in the above model the income of any individual simply depends on the amounts of labor and capital they provide to the market, and not on which industry they work for or invest in. In order to capture this, we instead assume that at the date that policy is being set factors cannot change industries, even if the supply of factors to their current industry can adjust in response to policy changes. In addition, for simplicity we assume that individuals work and invest in the same industry.

As shown in Bernheim and Winston (1986), the equilibrium bribes in such a setting are equivalent to those in which lobbying industries pay monetary bribes to officials equivalent to the benefits they receive due to the policies adopted by the government, relative to a given fallback position. The equilibrium bribe by industry $j$, denoted by $B_{j}$, then satisfies: $V_{j}\left(p_{1}\left(1+\tau_{1}\right), p_{2}\left(1+\tau_{2}\right), r_{j}, w_{j} ;-B_{j}\right)+W_{j}(G)=U_{j}^{*}$. The default utility level, $U_{j}^{*}$, is determined from the constraint that the bribe must be sufficient to allow the government and the other bribing industries to do as well as they could have done collectively had this one industry not actively bribed the government - if not, the bribe would not be accepted. 
For simplicity, we assume that bribes are as valuable to officials as explicit but unspent tax revenue. Certainly, both are cash that officials can use to finance perks if not private consumption. The only difference is that oversight and possible punishment for accepting under-the-table payments may be different than for using tax revenue for personal advantage. ${ }^{16}$ To the extent bribes are less valuable to officials than extra tax revenue, then equilibrium tax rates in lobbying industries will be higher than we find below, and conversely.

If $j \in L$ is the set of industries that actively lobby the government, then the resulting objective function for the government is:

$$
\max _{\tau_{2}, s_{1}, s_{2}, t_{K}, G}\left(\sum_{j \notin L}\left(V_{j}+W_{j}\right)+\sum_{j \in L}\left(U_{j}^{*}\right)+S\left(\sum_{j} p_{j}\left(f_{j}-C_{j}\right)-G\right)\right)
$$

where we assume a composite individual working for each industry. Here, bribes show up implicitly in government revenue through their effects on equilibrium consumption among members of lobbying industries.

The resulting first-order conditions for $s_{k}$ equals

$$
\begin{aligned}
& S^{\prime}\left(\sum_{j} p_{j}\left(\frac{\partial f_{j}}{\partial s_{k}}-\frac{\partial C_{j}}{\partial s_{k}}\right)\right)=V_{k I}\left(p_{k}\left(1+\tau_{k}\right) f_{k}\right) \quad \text { for } k \notin L \\
& \sum_{j} p_{j}\left(\frac{\partial f_{j}}{\partial s_{k}}-\frac{\partial C_{j}}{\partial s_{k}}\right)=0 \quad \text { for } k \in L .
\end{aligned}
$$

where $V_{k I}$ denotes the marginal utility of income for the $k^{\prime}$ th individual. For nonbribing industries, the government trades of the revenue it gets with the welfare loss to individuals. Since we assume that $S^{\prime}>V_{k I}$, in equilibrium the efficiency costs of the tax must at the margin just offset the welfare gain from shifting a given amount of resources to the government. Note that an increase in the sales tax rate on lobbying industries

\footnotetext{
${ }^{16}$ Grossman-Helpman (1994), in contrast, assume that bribes can only be spent on political campaigns, reflecting current institutional constraints in the U.S. There are no similar constraints to our knowledge in any developing country.
} 
matters only to the extent that it affects government revenue. No individual utilities change, since consumer prices are unaffected, while the effects on utility of any changes in factor prices in lobbying industries are fully offset through changes in the bribes.

The individuals' collective budget constraint equals

$$
\begin{aligned}
& \sum_{j} p_{j}\left(1+\tau_{j}\right) C_{j}+\sum_{j \in L} B_{j}=\sum_{j} p_{j}\left(1-s_{j}\right)\left(1+\tau_{j}\right) f_{j}-t_{K} K, \text { implying that } \\
& \sum_{j} p_{j}\left(\frac{\partial f_{j}}{\partial s_{k}}-\frac{\partial C_{j}}{\partial s_{k}}\right)=\delta_{k} p_{k}\left(1+\tau_{k}\right) f_{k}+\sum_{j} p_{j} \tau_{j} \frac{\partial C_{j k}}{\partial s_{k}}+t_{K} \frac{\partial K_{k}}{\partial s_{k}}+p_{k}\left(s_{k}\left(1+\tau_{k}\right)-\tau_{k}\right) \frac{\partial f_{k}}{\partial s_{k}},
\end{aligned}
$$

where $\delta_{k}=1$ for $k \notin L$ and $\delta_{k}=0$ otherwise.

Substituting into equation (4), it is straightforward to show that

$$
\delta_{k}\left(1-\frac{V_{k I}}{S^{\prime}}\right)-\sum_{j} p_{j} \tau_{j} \varepsilon_{I}^{C_{j k}} \frac{C_{j k}}{I_{k}}-t_{K} \varepsilon_{p_{k}^{*}}^{K_{k}} \frac{K_{k}}{p_{k}^{*} f_{k}}=\frac{s_{k}\left(1+\tau_{k}\right)-\tau_{k}}{\left(1-s_{k}\right)\left(1+\tau_{k}\right)} \varepsilon_{p_{k}^{*}}^{f_{k}},
$$

where, $\varepsilon_{Y}^{X}$ represents the elasticity of $X$ with respect to $\mathrm{Y}$, where

$p_{k}^{*} \equiv p_{k}\left(1+\tau_{k}\right)\left(1-s_{k}\right)$ and where $I_{k}=p_{k}^{*} f_{k}-t_{K} K_{k}$. All three elasticities are positive under any reasonable assumptions.

To begin with, equation (6) suggests that the optimal effective tax rate $s_{k}\left(1+\tau_{k}\right)-\tau_{k}$ will be negative for industries actively bribing the government to the extent $\tau_{2}>0$ and $t_{K}>0$. At the optimum, a marginal increase in the subsidy to production in a lobbying industry should have no net effect on government revenue. While a marginal increase in the subsidy is in itself a net revenue cost, since more output needs to be subsidized, the extra production also generates extra revenue to the extent that the resulting increases in investment and consumption are taxable. At the optimal tax rates, these effects should exactly offset each other. 
For firms not actively bribing the government, for whom $\delta_{k}=1$, optimal tax rates presumably will be positive. If the three elasticities in equation (6) are the same among these industries, if there are no differences in the marginal utility of income across these industries, and if consumption patterns are the same for people in all industries, then the effective tax rate will be lower in more capital-intensive industries if $t_{K}>0$, in effect to compensate for this other source of revenue from these industries.

The key forecasted difference in sales tax rates is then between industries that actively bribe officials and other industries. The forecast of a lower (or negative) tax rate on capital-intensive industries is one clear difference between the political economy model and the Gordon-Li model.

What about the optimal tariff rate? Consider the welfare effects of an increase in $\tau_{m}$ on imports of goods produced by bribing industries, with a compensating increase in $s_{m}$ so as to leave $s_{m}\left(1+\tau_{m}\right)-\tau_{m}$ consistent with equation (6). This combined change in tax rates has no effects on the factor incomes of any individual, so does not help per se to redistribute to individuals in bribing industries. It does raise the consumer price for good $m$ faced by all individuals, so helps aid those in lobbying industries to the extent that individuals in these industries tend NOT to consume the output from their own industries. As discussed in Saez (2002), such a tariff may also be justified on efficiency grounds if a drop in consumption of good $m$ leads to increases in factor supplies beyond what happens simply due to income effects.

Neither of these justifications for a tariff would exist if the utility function is weakly separable between consumption and factor supplies, e.g. $U\left(L, K, h\left(C_{1}, C_{2}\right)\right)$, and if the utility function is the same for individuals in different industries. Even if these assumptions are violated, there is no reason to expect that individuals working in favored industries tend NOT to consumer output from these industries, or that factor supplies are more responsive to the prices of goods produced by capital-intensive industries. The model does not then help to explain the existence of tariffs protecting favored industries. 
To what degree would subsidies to capital $\left(t_{K}<0\right)$ be used to aid bribing (capitalintensive) industries? Even better targeted would be a subsidy to capital invested in bribing industries, implemented for example through subsidized loans restricted to these industries. ${ }^{17}$ Note that a reduction in the output tax rate, $s_{k}$, affecting bribing industries is equivalent to a proportional subsidy to both capital and labor employed within this industry. When could a further subsidy just to capital in the industry be chosen?

If all the individuals working in the industry collude together in bribing the government, then the government receives the benefits accruing to both groups, so a capital subsidy per se makes sense only if it has favorable efficiency effects. This could occur if the supply elasticity of capital is less than that for labor. As noted by Judd (1987), while the very short-run supply of capital is extremely inelastic, the long run supply in contrast should be extremely elastic, suggesting if anything attempts to restrict taxes/subsidies to labor whenever the government has a longer time perspective.

If only the capital owners in an industry bribe the government, then the government does have an incentive to manipulate the returns to labor vs. capital in the industry. Natural policies suggested by such an objective are subsidized loans to the industry or a tax structure within the industry favoring capital over labor income.

If capital but not labor is highly mobile across industries, the model would instead forecast a low uniform tax (or subsidy) rate on capital, a high tax rate on labor in the disfavored industries, and no tariffs. Following equation (6), the labor income tax rate in favored industries would have the opposite sign of the tax/subsidy rate on capital.

Whether capital is mobile or not, these results contrast sharply with the forecasts from the Gordon-Li model, which forecasts capital taxes as a way to focus the tax burden on firms

\footnotetext{
${ }^{17}$ To induce banks to provide subsidized credit to particular customers, explicit subsidies to such loans, or loan guarantees, would be one approach. State ownership of the banking sector, with the government covering losses incurred on subsidized loans, is another.
} 
that are most dependent on the financial sector, and heavier tax payments by capitalintensive than by labor-intensive firms.

If the government for some reason could not provide the desired differential sales or labor income tax rates in favored vs. disfavored industries, then tariffs can be a second-best way of favoring certain industries. A tariff is second best since not only does it raise the returns earned within that industry but it also distorts consumer choices in ways that in general are not desired. In contrast to the Gordon-Li model, tariff protection would be given to sectors facing the lowest rather than the highest tax rates.

Grossman-Helpman (1994) fully recognized that their model would imply output subsidies for lobbying industries and no tariffs as long as the government can freely make use of this full range of policy tools. They assumed, though, that output subsidies were not available as an option to the government. The complication they note to justify this assumption arises from implications for the default utility levels $U_{j}^{*}$. Each industry must pay enough in bribes to ensure that the government plus other bribing industries together are at least as well off as they would be if they refuse the bribe. If these groups are in a position to aggressively exploit any given industry, then this industry will need to pay them a lot in exchange for changing policies. Their opportunity to exploit any given industry is less if policies are restricted to tariffs. They argue that this consideration dominates if there are few other industries that are not lobbying, since benefits to a newly lobbying industry then must come almost entirely from those who must be bribed. If the group of other industries that are not lobbying is large, however, then this issue will be second order relative to the gains from use of a more effective policy tool.

Among richer countries, where we presume that most industries actively lobby the government, their argument suggests that policies will be restricted to tariffs. ${ }^{18}$ If the fraction of industries that actively lobby the government is small in developing countries,

\footnotetext{
${ }^{18}$ Lobbying industries would need to make this decision collectively, however, and in an enforceable way, since each industry on its own would prefer to be aided through output subsidies rather than tariff protection. While we know of no such explicit restrictions on policy, it is true that excise taxes/subsidies play much less of a role in richer countries than in poorer countries.
} 
then even by their argument we would not expect to see any such restrictions on policy. In fact, excise taxes are an important component of the tax systems in developing countries. According to the political-economy model, this should not be surprising. But given this, tariffs should not be used.

In the Grossman-Helpman model, the more industries that lobby the government the lower is overall tax revenue. (Bribes of course do not show up in the reported revenue figures.) If fewer industries actively bribe the government in developing countries, then the size of government should be larger in developing countries, a forecast sharply contrary to the forecast from the Gordon-Li model.

Another implication of the political-economy model is that as more industries actively bribe the government, concern with redistribution shrinks. In particular, the government has no ability left to affect the utility levels within bribing industries, since they are implicitly set at the default levels $U_{j}^{*}$. Any redistribution is restricted to individuals in nonbribing industries, yet the offsetting efficiency costs remain fully relevant. The larger the number of individuals working in bribing industries, therefore, the less is the concern with redistribution. If fewer industries are actively involved in bribery in developing countries, then these countries should focus more on redistributive effects of the tax structure, so should place more weight on such taxes as the personal income tax that are particularly effective at shifting the tax burden from rich to poor. This forecast is strongly contrary to that coming out of the Gordon-Li model, where taxes on labor income should play little role in poorer countries.

Does the model make any forecasts regarding the extent of state ownership of firms? One potential role for state ownership is to ensure that promised bribes are in fact paid, making it easier for the government to change policy as promised. The importance of this assurance must be traded off with any efficiency costs per se from state ownership. The equilibrium bribes paid by an industry will be large when few under industries lobby, since the industry can potentially gain substantially at the expense of nonlobbying industries. This would be the setting where the benefits from ensuring such payments 
through state ownership are largest. The model therefore suggests a larger role for state ownership in the poorest countries, where the fraction of industries that lobby is presumably the smallest.

Within this political-economy model, there are no incentives per se to use inflation there is no motivation for use of cash beyond those in the standard model. Similarly, there are no grounds for introducing red tape and other nontax forms of harassment. If activity in unfavored sectors is to be penalized, better to do it through the tax structure and collect revenue in the process.

\section{Data on behavior of poorer vs. richer countries}

We turn next to an analysis of available data on tax and related policies among a group of 125 countries for which we could obtain adequate data. ${ }^{19}$ In the Appendix, we list our data sources and the definition of the variables used in this paper. In reporting data, we have grouped these countries into four quartiles based on their GDP per capita in 1990 measured in constant 2000 U.S. dollar. Quartile 1 represents the richest countries, and quartile 4 the poorest.

We focus first on the evidence regarding forecasts from the Gordon-Li (GL) and the "political economy" (PE) models when they are the same, and then turn to forecasts that conflict between the two models.

Throughout we treat skill/technology differences across countries as exogenous, driving not only differences in GDP per capita but also the quality of the financial sector and the ease with which firms within an industry can coordinate on lobbying. Certainly, the types of policy differences we focus on can affect a country's long-run growth rate, and

\footnotetext{
${ }^{19}$ We would very much like to thank Andrei Shleifer for making available to us the data used in La Porta et al (2002) and Friedrich Schneider for making available to us his estimates of the size of informal economy.
} 
the utility provided from employing existing factor inputs, but these policy differences should have little direct effect on factor supplies or on overall output.

\section{Similar forecasts in the two models}

Table 1 provides information regarding several forecasts that are comparable in the two models, even if the rationales are very different.

One forecast in common is that the tax structure in poorer countries will make more use of taxes with differential rates by industry. In the Gordon-Li model, tax rates will be higher on the capital-intensive industries, since they cannot so easily shift into the informal sector. In the political economy model, tax rates will be lower for capitalintensive industries, responding to their active lobbying efforts. So both models forecast rate differences by industry, though the direction of the forecasted rate differences are opposite.

The key tax whose rate easily varies by industry is nongeneral taxes on production and sales, primarily consisting of excise taxes. Column 2 of Table 1 reports the fraction of tax revenue coming from nongeneral production taxes. The data show little variation in the use of excise taxes by income level, possibly because sin taxes and environmental (e.g. gasoline) taxes play a more important role in richer countries, offsetting the role of excise taxes both models focus on.

Unfortunately, at this point we have no data sufficient to test the conflicting forecasts between the two theories regarding which industries face lower vs. higher tax rates. While our understanding is that poorer countries rely heavily on revenue from capitalintensive industries, particularly oil, mining, and other extractive industries, where tax collection is particularly easy, we have not at this point found data to confirm this impression. 
Both models plausibly forecast more use of taxes on capital income among poorer countries. In the Gordon-Li model, this occurs in order to shift the tax burden onto the firms that are least likely to shift into the informal sector in response. If capital is mobile across sectors, then the political economy model trades off the desire to tax capital in nonlobbying industries and to subsidize capital in lobbying industries. If the aggregate size of the lobbying sectors is smaller in poorer countries, then capital-income taxes should be higher in these countries. We presume that the corporate income tax represents the main tax on income from capital and report the share of revenue coming from the corporate income tax in column 3 of Table 2. This share shows a weak pattern of being higher in poorer countries, but the evidence is not dramatic.

Both models also suggest that poorer countries could well use state-owned banks as a mechanism to provide cheap credit to capital-intensive firms. In the Gordon-Li model, this is done to redirect credit to sectors paying high tax rates. In the political-economy model, this is done if capital owners in particular lobby the government. As seen in column 4 in Table 1, the fraction of the ten largest banks owned by the government is substantially higher in poorer than in richer countries, though state ownership of banks is still nontrivial even in rich countries. No data are available on whether firms receiving subsidized loans pay unusually low or unusually high tax rates.

Both models also forecast a larger role for state-owned firms among poorer countries. In the Gordon-Li model, state ownership is used to offset the distortions created by the high tax rates on these firms. In the political-economy model, this occurs to ensure that bribes are paid, which would be particularly important when few firms actively lobby the government, generating large potential benefits to these sectors.

\section{Contrasting forecasts in the two models}

One clear difference in the forecasts from the two models regards the size of tax revenue relative to GDP. In the Gordon-Li model, enforcement is more difficult in poorer countries, due to a poorer quality financial sector, so that revenue is lower. In contrast, in 
the political economy model, tax revenue is higher in poorer countries given the assumption that fewer industries actively lobby the government. The evidence is reported in column 1 of Table 2 . Here, we find that revenue as a fraction of GDP in the richest quartile is double that in the poorest quartile, and a strongly increasing function of per capita GDP, consistent with the GL but not the PE model.

The two models also have conflicting forecasts regarding the use of tariffs. In the Gordon-Li model, tariffs would clearly be attractive if the country is a net importer of capital-intensive goods. ${ }^{20}$ In the political economy model, tariffs would not be used unless lobbying industries collectively manage to restrict any aid they receive to take the form of tariff protection. The model forecasts that this restriction could well be imposed in richer countries, where most industries lobby the government, but not in poorer countries. The evidence on tariffs is reported in column 2 of Table 1. Tariffs are used far more heavily in poorer countries, consistent with the GL but not the PE model.

Another forecast that differs across the two models regards the use of the personal income tax or broad based taxes on consumption. In the Gordon-Li model, such taxes on labor income (when earned or spent) should play little role, since this shifts the tax burden onto the firms least tied to the financial sector. In contrast, in the politicaleconomy model, redistribution should matter more in poorer countries, where a smaller fraction of the economy is actively involved in lobbying. The data on the fraction of tax revenue collected by the personal income tax and general taxes on goods and services is reported in column 3 of Table 2, and shows much more of a role for broad-based taxes in richer countries, consistent with GL.

Another difference between the two models regards inflation. The Gordon-Li model forecasts inflation as a way to tax the informal sector, representing the only sector that relies heavily on cash transactions. The political economy model follows the conventional optimal tax model in forecasting no use of an inflation tax. The size of

\footnotetext{
${ }^{20}$ In standard trade models, poor countries specialize in labor-intensive industries, so should be importers of capital-intensive goods.
} 
seignorage as a fraction of GDP is reported in column 4 of Table 2. Here we do find that poorer countries rely far more heavily on inflation taxes than do richer countries, consistent with GL.

A further difference regards the use of red tape to hinder activity in labor-intensive sectors, and in the informal sector. Such policies fall out naturally in the Gordon-Li model as ways to hinder activity in sectors that pay little or no taxes. In the political economy model, regular income and sales taxes dominate use of red tape. In columns 5 and 6 of Table 2 we report data on two indicators of red tape: a) the cost to register a new business, and b) the time required to start a business legally. Both types of costs are clearly higher in poorer countries, consistent with GL.

The two models focus on very different attributes of an economy in making forecasts for policy. In the Gordon-Li model, the driving force is a poorly functioning financial sector, making it all too easy for firms to shift into the cash economy in order to avoid taxes. We should then see poorer countries having much larger informal sectors, because of their more poorly functioning financial sectors. In the political economy model, rather than having the small firms that constitute the informal sector being de facto tax exempt, taxes should fall primarily on these firms. Data on the size of the informal sector are reported in column 7 of Table 2. The size of the informal sector as a fraction of GDP in the poorest quartile is more than double that in the richest quartile, consistent with GL.

To test for evidence that the informal sector tends to be large when the financial sector functions poorly, we ran a regression forecasting the size of the informal sector as a function of one or another indicator of the quality of the financial sector, along with $\log$ (per capita GDP), average literacy, and population density as control variables. Results are reported in Table 3. A poorly functioning financial sector strongly predicts a large informal sector, whereas the other control variables play little role.

In the political-economy model, the key driving force of course is political lobbying pressure that leads governments to favor one sector over another. If politics is playing 
such a dominant role in the choice of tax policy, we would expect to see very different tax policies chosen by governments that are classified as left-wing vs. right-wing. To provide some evidence on this, we recalculate the figures on tax policy reported in Table 1 , instead classifying countries into four quartiles based on their ideological orientation, with quartile 1 being the most right wing and quartile 4 being the most left wing. Results appear in Table 4. Here, we find that ideology has no obvious connection to tax policy, except perhaps for a higher reliance on tariffs by the most left-wing governments.

\section{Conclusions}

Tax policies in practice differ dramatically between poorer and richer countries. Richer countries rely primarily on broad-based income and consumption taxes, and make little use of tariffs or seignorage as sources of revenue. Poorer countries, in contrast, make much less use of broad-based taxes, relying instead on excise taxes, tariffs, and seignorage. In the process, though, they collect much less revenue as a fraction of GDP than is collected in richer countries. Corruption and red tape are also far more common in poorer countries.

The question this paper focuses on is why these policy differences arise. We develop the implications of two alternative models for such policy differences. One, a model initially developed in Gordon-Li (2005), focuses on the tax enforcement problems that arise when firms find it easy to shift into the cash economy, thereby avoiding leaving any paper trail and making tax enforcement extremely difficult. The government is then left relying for revenue on the remaining industries that cannot so easily shift into the cash economy to evade tax. With such large differential tax rates, a wide range of other policies may make sense as second-best means to lessen the resulting misallocations. Within this model, the policies forecast are "third" best, handling as well as is feasible the informational problems faced in collecting revenue. 
The second model assumes that the political pressures faced in poorer countries are very different than in richer countries, leading to a very different set of policy choices. If particular industries in poorer countries have been able to lobby the government effectively for protection, then the chosen policies can be very different than when political support for the government is more broad-based, at least across industries. If such political pressures explain the perverse policies chosen in poorer countries, then there are clear grounds for using international agencies to help induce countries to shift to policies more in the interests of their population as a whole.

In this paper, we explore the implications of such a political-economy model in detail, building on the framework developed in Grossman-Helpman (1994). While such a model easily forecasts more favorable sales tax rates or income tax rates on factors employed in favored industries, it does not so easily explain tariffs, seignorage or red tape. Only if sales or income tax rates cannot vary by industry to the extent desired might tariffs make sense.

The paper then reexamines the data to see to what degree each model is consistent with the data. Some forecasts are naturally in common, while others are very different. Other forecasts are very different. As discussed in the paper, the forecasts from the two models differ sharply with regard to the relative use of tariffs, seignorage, capital-income taxes, personal-income taxes, and the overall size of tax revenue in poorer vs. richer countries. In each case, the forecasts from the Gordon-Li model are very much consistent with the data, while those from the political-economy model are not.

The paper in addition examines data related to the key underpinnings of each model. In the Gordon-Li model, a weak financial sector implies that little is lost by a firm from shifting to the cash economy as a means of evading taxes. Countries with a poorly functioning financial sector should then as a result have a large informal economy, and with a large informal economy choose a "perverse" tax structure to deal with the resulting pressures. We document both such relationships. 
In the political-economy model, tax policy should depend heavily on the nature of the political pressures faced by the government. Left-wing governments represent ones that face very different pressures than right-wing governments, so should choose very different tax policies. We examine to what degree this is true, and find little difference in tax policies across governments of different ideologies.

Unfortunately, some of the key differences are not at this point testable, e.g. the GordonLi model forecasts that the highest tax rates will be paid by capital-intensive industries (that find it hardest to shift to the cash economy), whereas in the political economy model these industries should face the lowest tax rates (since they can most easily solve the internal free-rider problems and lobby the government for support).

The data at this point are limited, so no tests are definitive. That the implications of the two models for policy are so different implies that much is at stake in such tests. Within the political-economy model, the key problem is differences in the political pressures faced in poorer than in richer countries, and in particular the smaller fraction of industries in poorer countries that are organized enough to lobby the government. Outside pressure to adopt more conventional tax policies can potentially compensate as a way to aid the population as a whole. In the Gordon-Li model, in contrast, the key problem is a weak financial sector, making tax evasion easy. Reform efforts then need to focus on improving the quality of the financial sector. Outside pressure to shift to more conventional tax policies, without simultaneously improving the financial sector, will likely cause more harm than good.

There certainly is a large body of empirical work at this point suggesting the importance of financial sector reforms in economic growth. The Gordon-Li model provides a different underpinning for the role financial reform plays, arguing that financial reform improves not only the allocation of credit across firms but also induces a shift in government policies more broadly to ones that create fewer distortions to market allocations. 


\section{References}

Beck, Thorsten, Asli Demirgüç-Kunt and Ross Levine, (1999), "A New Database on Financial Development and Structure," Policy Research Working Paper No. 2146, Washington DC: World Bank.

Beck, Thorsten, George Clarke, Alberto Groff, Philip Keefer, and Patrick Walsh. 2001. "New tools in comparative political economy: The Database of Political Institutions." 15:1, pp. 165-176, World Bank Economic Review.

Diamond, Peter and James Mirrlees. 1971. "Optimal Taxation and Public Production," American Economic Review 61, pp. 8-27.

Djankov, Simeon, Rafael La Porta, Florencio Lopez de Silanes, and Andrei Shleifer. 2002. "The Regulation of Entry," Quarterly Journal of Economics, February.

Friedman, Milton. 1969. "The Optimal Quantity of Money." In The Optimal Quantity of Money and Other Essays, edited by Milton Friedman. Chicago: Aldine Publishing Company.

Gordon, Roger and Wei Li. 2005. "Tax Structure in Developing Countries: Many Puzzles and a Possible Explanation," NBER Working Paper No. 11267.

Grossman, Gene and Elhanan Helpman. 1994. "Protection for Sale," American Economic Review 84, pp. 833-50.

La Porta, Rafael, Florencio Lopez de Silanes, and Andrei Shleifer. 2002. "Government Ownership of Banks," Journal of Finance, February. 
International Monetary Fund. 2004. Government Financial Statistics, CD-ROM (May).

International Monetary Fund. 2005. International Finance Statistics, IFS Online, accessed between February and April 2005.

Judd, Kenneth. 1987. "The Welfare Cost of Factor Taxation in a Perfect-Foresight Model," Journal of Political Economy 95, pp. 675-709.

Saez, Emmanuel. 2002. "The Desirability of Commodity Taxation under Non-linear Income Taxation and Heterogeneous Tastes," Journal of Public Economics 83, pp. 21730.

Schneider, Friedrich and Dominik Enste. 2000. "Shadow economies: Size, causes, and consequences," Journal of Economic Literature 38/1, pp. 77-114.

Schneider, Friedrich. 2004. "The Size of Shadow Economies in 145 Countries from 1999 to 2003," mimeo, Johannes Kepler University of Linz, Austria.

World Bank. 2005. World Development Indicators, WDI Online, accessed March and April, 2005. 


\section{Table 1}

\section{Tests when Forecasts are Similar}

Countries are classified by GDP per capita in 1990 into four quartiles with Quartile 1 the richest and Quartile 4 the poorest. The number in each cell is the average of each listed variable among countries in each income quartile.

\begin{tabular}{|c|c|c|c|c|c|}
\hline & $\begin{array}{c}\text { GDP per } \\
\text { capita in } \\
\mathbf{1 9 9 0} \\
(\mathbf{2 0 0 0} \$)\end{array}$ & $\begin{array}{c}\text { Excise Taxes } \\
(\% \text { of revenue) }\end{array}$ & $\begin{array}{c}\text { Corporate Taxes } \\
\text { (\% of revenue, } \\
\mathbf{1 9 9 0 - 2 0 0 1} \text { average) }\end{array}$ & $\begin{array}{c}\text { \% Government } \\
\text { Ownership of } \\
\text { Banks, 1995 }\end{array}$ & $\begin{array}{c}\text { SOE } \\
\text { Output } \\
\text { \% of GDP }\end{array}$ \\
\hline $\begin{array}{c}\text { Quartile } \\
\mathbf{1}\end{array}$ & 20768 & 19.6 & 9.5 & 24.2 & 0.1 \\
\hline $\begin{array}{c}\text { Quartile } \\
\mathbf{2}\end{array}$ & 3834 & 16.2 & 17.9 & 40.5 & 1,8 \\
\hline $\begin{array}{c}\text { Quartile } \\
\mathbf{3}\end{array}$ & 1451 & 19.5 & 14.2 & 47.0 & 1.5 \\
\hline $\begin{array}{c}\text { Quartile } \\
\mathbf{4}\end{array}$ & 436 & 20.3 & 14.2 & 67.2 & 8.4 \\
\hline
\end{tabular}




\section{Table 2}

\section{Tests when Forecasts Differ}

Countries are classified by GDP per capita in 1990 into four quartiles with Quartile 1 the richest and Quartile 4 the poorest. The number in each cell is the average of each listed variable among countries in each income quartile.

\begin{tabular}{|c|c|c|c|c|c|c|c|}
\hline & $\begin{array}{c}\text { Tax } \\
\text { Revenue } \\
\text { (\% of } \\
\text { GDP, } \\
1990- \\
2001 \\
\text { average) }\end{array}$ & $\begin{array}{c}\text { Tariff } \\
\text { Revenue } \\
\text { (\% of } \\
\text { revenue) } \\
1990=2001 \\
\text { average }\end{array}$ & $\begin{array}{c}\text { Personal } \\
\text { Income } \\
\text { plus Sales } \\
\text { Taxes } \\
\text { (\% of tax } \\
\text { revenue, } \\
1990-2001 \\
\text { average) }\end{array}$ & $\begin{array}{c}\text { Seignorage } \\
\text { (\% of } \\
\text { GDP, } \\
1990-2001 \\
\text { average })\end{array}$ & $\begin{array}{c}\text { Cost to } \\
\text { Register a } \\
\text { Business } \\
\text { (\% of } \\
\text { GNI per } \\
\text { capita, } \\
2001-02 \\
\text { average) }\end{array}$ & $\begin{array}{c}\text { Time to } \\
\text { Start a } \\
\text { Business } \\
\text { (days, 2001- } \\
\text { 02 average) }\end{array}$ & $\begin{array}{c}\text { Informal } \\
\text { Economy } \\
\text { (\% of } \\
\text { GDP, } \\
\text { 1990/91) }\end{array}$ \\
\hline $\begin{array}{c}\text { Quartile } \\
1\end{array}$ & 26.6 & 6.0 & 50.0 & 0.5 & 0.11 & 32 & 13.5 \\
\hline $\begin{array}{c}\text { Quartile } \\
2\end{array}$ & 21.4 & 17.7 & 37.0 & 1.7 & 0.21 & 57 & 26.9 \\
\hline $\begin{array}{c}\text { Quartile } \\
3\end{array}$ & 17.5 & 22.3 & 32.7 & 2.1 & 0.50 & 63 & 34.2 \\
\hline $\begin{array}{c}\text { Quartile } \\
4\end{array}$ & 13.3 & 28.8 & 30.2 & 2.3 & 1.97 & 66 & 28.8 \\
\hline
\end{tabular}




\section{Table 3}

\section{Factors Affecting Size of Informal Economy}

Columns (1) and (2) show estimates of coefficients and their standard errors resulting from ordinary least squares regressions on the cross-section of countries. The dependent variable is the size of informal economy in 2001. Numbers in parentheses are standard errors. $* * *$ indicates $1 \%$ level of significance, while * indicates $10 \%$ level of significance.

\begin{tabular}{|l|c|c|}
\hline & $(\mathbf{1})$ & $(\mathbf{2})$ \\
\hline Overhead costs & 2.12 & \\
\hline Interest rate spread & $(0.059)^{* * *}$ & 1.28 \\
& & $(0.52)^{* * *}$ \\
\hline Log(GDP per capita) & -0.021 & -0.020 \\
& $(0.014)^{*}$ & $(0.016)$ \\
\hline Adult literacy rate & -0.122 & -0.063 \\
& $(0.093)$ & $(0.095)$ \\
\hline Log(population density) & -0.002 & -0.004 \\
& $(0.01)$ & $(0.01)$ \\
\hline Number of observations & 64 & 64 \\
\hline Adjusted $\boldsymbol{R}^{2}$ & 0.261 & 0.181 \\
\hline
\end{tabular}


Table 4

\section{Tests for Role of Ideology in Tax Policy}

Countries are classified into four quartiles by the average ideological orientation of the chief executive's party in the period 1980 to 1989 with Quartile 1 the most right wing and Quartile 4 the most left wing. The number in each cell is the average of each listed variable among countries in each income quartile.

\begin{tabular}{|c|c|c|c|c|c|}
\hline & $\begin{array}{c}\text { GDP per } \\
\text { capital } \\
\mathbf{1 9 9 0} \\
\mathbf{2 0 0 0}\end{array}$ & $\begin{array}{c}\text { Tax Revenue } \\
\text { (\% of GDP) }\end{array}$ & $\begin{array}{c}\text { Tariff } \\
\text { Revenue } \\
\text { (\% of GDP) }\end{array}$ & $\begin{array}{c}\text { Income taxes } \\
\text { (\% of } \\
\text { revenue) }\end{array}$ & $\begin{array}{c}\text { Income Taxes } \\
\text { + VAT } \\
\text { (\% of } \\
\text { revenue) }\end{array}$ \\
\hline Quartile 1 & 6956 & 20.0 & 15.8 & 31.9 & 45.6 \\
\hline Quartile 2 & 10778 & 22.3 & 13.6 & 36.2 & 48.9 \\
\hline Quartile 3 & 8465 & 23.9 & 11.3 & 31.7 & 48.3 \\
\hline Quartile 4 & 2556 & 17.7 & 26.3 & 30.5 & 46.1 \\
\hline
\end{tabular}




\section{Appendix \\ Description of the variables}

\section{Variable name}

\section{Description and source}

Taxation

Tax revenue (\% of Tax revenue (GFS line 11) as a proportion of GDP, average for the period GDP) 1990 to 2001. Source: Authors' calculation based on IMF (2004), Government Finance Statistics (May 2004 CD-ROM).

Tariff revenue $(\%$ of GDP)

Income taxes $(\%$ of revenue)

VAT $(\%$ of revenue)

Corporate income taxes $(\%$ of revenue)
Taxes on international trade and transactions (GFS line 115) as a proportion of GDP, average for the period 1990 to 2001. Source: Authors' calculation based on IMF (2004), Government Finance Statistics (May 2004 CD-ROM),

Sum of personal and corporate income taxes (GFS line 1111 and 1112) as a proportion of tax revenue (GFS line 11), average for the period 1990 to 2001. Source: Authors' calculation based on IMF (2004), Government Finance Statistics (May 2004 CD-ROM).

Value-added taxes (GFS line 11411) as a proportion of tax revenue (line 11), average for the period 1990 to 2001.

Corporate income taxes (GFS line 1112) as a proportion of tax revenue (GFS line 11), average for the period 1990 to 2001. Source: Authors' calculation based on IMF (2004), Government Finance Statistics (May 2004 CD-ROM).

Seignorage $(\%$ of revenue)
Seignorage is measured as the increase in reserve money (IFS line 14). Source: Authors' calculation based IFS On-Line published by the International Monetary Fund, accessed between February and April 2005. 


Cost to Register a
Business
(\% of GNI per
capita)

Time to Start a

Business

(days)

The cost of obtaining legal status to operate a firm as a share of per capita GNI, average for 2001 and 2002. It includes all identifiable official expenses. Source: World Development Indicators 2005 On-Line Edition, accessed in March and April, 2005. For data methodology, see Djankov, La Porta, Lopez-de-Silanes and Shleifer (2002).

The time it takes to obtain legal status to operate a firm, in business days, average for 2001 and 2002. Source: World Development Indicators 2005 On-Line Edition, accessed in March and April, 2005. For data methodology, see Djankov, La Porta, Lopez-de-Silanes and Shleifer (2002).

\section{Informal economy}

Size of informal Measured as the size of shadow economy estimated by Schneider (2004), economy (\% of using methodology documented in Schneider and Enste (2000). Estimates GDP) for 1990-91 and 2001-02 are used in this paper.

\section{Government ownership}
Government Share of the assets of the top 10 banks in a given country owned by the ownership of banks in 1995 government of that country in 1995. Source: La Porta, Lopez-De-Silanes and Shleifer (2002)

SOE output $(\%$ of GDP)

SOE value added of all non-financial SOEs as a proportion of GDP of the economy at market prices, average for the period 1978 to 1981. Source: The World Bank (1995), La Porta, Lopez-De-Silanes and Shleifer (2002).

\section{Quality of the financial sector}

Overhead costs, Accounting value of a bank's overhead costs as a share of its total assets, 1980-89 average for the period 1980 to 1989. Source: Beck, Demirgüç-Kunt and 
Levine (1999), updated data published March 14, 2005.

Interest rate

spread, 1980-89

Right wing

ideology, 1980-89
Accounting value of bank's net interest revenue as a share of its interestbearing (total earning) assets, average for the period 1980 to 1989.

Source: Beck, Demirgüç-Kunt and Levine (1999), updated data published March 14, 2005.

\section{Ideology}

Average of the ideological orientation of the chief executive's party for the period 1980 to 1989 . The ideological orientation is coded as 1 for right, 0 for center, and -1 for left.

\section{Other variables}

GDP per capita, GDP per capita in 2000 constant dollar, converted using market or official 1990 exchange rate. Source: World Development Indicators 2005 On-Line Edition, published by the World Bank, accessed in March and April, 2005.

Adult literacy rate, Percent of people ages 15 and above who are literate, average for the 1980-89 period 1980 to 1989. Source: World Development Indicators 2005 OnLine Edition, published by the World Bank, accessed in March and April, 2005.

Population Number of people per square kilometer, average for the period 1980 to density, 1980-89 1989. Source: World Development Indicators 2005 On-Line Edition, published by the World Bank, accessed in March and April, 2005. 